\author{
УДК 3.38, JEL G34 \\ ORCID ID 0000-0002-2157-1422 \\ $0000-0002-8657-7278$ \\ $0000-0002-6538-1241$ \\ DOI https://doi.org/10.17721/tppe.2020.41.4
}

\author{
Dvulit Z., Doctor of Economics, Professor \\ Lviv Polytechnic National University \\ Mykytiuk O., PhD in Economics, Docent \\ Taras Shevchenko National University of Kyiv \\ Onysenko T., PhD in Economics \\ Taras Shevchenko National University of Kyiv
}

\title{
FEATURES OF MERGERS AND ACQUISITIONS IN THE PHARMACEUTICAL INDUSTRY
}

Increasing mergers and acquisitions in the pharmaceutical industry have raised fears that unprecedented market concentration will weaken competition. Two of the most important concerns for the pharmaceutical industry are concerns that these mergers will reduce the market for new developments, and concerns that the combination of large marketing efforts and sales will increase the influence of individual pharmaceutical manufacturers and weaken competition in the industry.

This article argues that none of the above dangers are systematically justified. However, there is a potential risk of market concentration at the stage of regulatory approval of mergers and acquisitions.

The rapid development of the pharmaceutical industry in a pandemic leads to the need to combine interests. That is why the consideration of the topic of mergers and acquisitions on the example of the pharmaceutical industry is very relevant.

The article identifies how these structural changes contribute to the current wave of mergers among active pharmaceutical market participants and how the potential harm of competition can be reduced.

Keywords: merger, acquisition, merger agreements, pharmaceuticals, combination of interests, enterprise

Problem statement. Pharmaceutical industry input to the nation's health and economic development makes it one the most important commercial sectors in the world and is on the front burner in current crisis conditions. In 2018 the worldwide pharmaceutical products sales volume was about 1 trillion dollars [16].

At the very same time, this sector is extremely controversial. Various approaches to pricing, marketing and products development strategy are often defining the enterprise behavior. Considering, that the decrease of prices for pharmaceutical products is vital to provide the affordable medical help, the Antimonopoly Committee of Ukraine has to interfere to prevent the unlawful pharmaceutical companies' mergers and acquisitions (M\&A).

Analysis of the up-to-date publications. The issues of the market concentration and its influence on the economy of the country is interesting for both Ukrainian and foreign researchers. The following local researchers payed their attention to the topic of the merger 
and acquisition process peculiarities: D. Gontar, O. Honcharova, A. Ignatyuk, V. Sabadash, S. Strapchuk, etc. Out of foreign scholars, who were working on concepts, principles and forms of M\&A agreements, we can mention the following: M. Bradley, 0 . Williamson, R. Coase, R. Nelson etc.

Issues not resolved. Controversy and incoherence between the processes of pharmaceutical market concentration and its competitive status are the points, that make this research relevant.

The aim of the article is to study the content and the effectiveness of the M\&A agreements in pharmaceutical industry and their influence of the level of the industry competitiveness.

The methodology of the research. The theoretical foundation of the research was formed by the studies of the prominent local and foreign scholars. The analytical research is performed, using not only general scientific methods, but also special methods. For instance, the method of theoretical generalization was used to analyze theoretical basis of notions "merger" and "acquisition". Abstract-logical method is used to identify the main factors that influence the M\&A agreements and their consequences for different subjects of the pharmaceutical market.

Research results. Regardless of the M\&A importance in the pharmaceutical industry and the history of M\&A throughout the past 100 years, the recent mergers of pharmaceutical giants during the previous decade are unprecedently consolidated.

It is a big and unsettling question whether the mergers of two giants to create another giant hurts the competitiveness of the whole market and innovative search in this industry.

The fear that the merger will loosen the competition is caused by two main issues. First of all, the merger of research and development, that the pharmaceutical enterprises are working on can cause the concentration of the innovations and discoveries, loosening of competition and decrease in experimental search for future. Another worrying issue is that the merger of the big pharmaceutical companies means also the merger of marketing efforts and distribution capacities, which, in its turn, can cause the increase of influence of certain pharmaceutical producers and lead to decrease of the prices pressure and rise the barrier to enter the market. To sum up, the activity of pharmaceutical companies, which leads to merger, is threatening in terms of prices increase, innovation decrease and reveals other structural blunders of the industry [13].

There are also some advantages of mergers in pharmaceutical industry. As opposed to innovations decrease, such processes can lead to more effective focus on economy and scale to facilitate the development. Furthermore, the mergers and open doors for new innovative players on the market, rather than decrease competition and innovative development.

This study is aimed to show, that companies' activity during the merger process is often associated with the more active productive developments and is crucial for global dynamic scientific and marketing environment. However, under some conditions merger and acquisition activity can create a risk of innovative capacity decrease. It means, that there is a potential need of R\&D productivity antimonopoly evaluation. The conclusions of the received results prove, that the pharmaceutical is an industry, where the mergers are 
caused by important technological and geopolitical changes and are not the tool to consolidate the pricing or market domination. However, there is a potential hazard to concentrate the market on a transitional stage of the pharmaceutical market development.

Mergers and acquisitions are known to happen since years 1800 [8]. Their quantity and frequency were increasing throughout time.

During 2008, the tendency of giant pharmaceutical companies merger continued. Each of the mergers was costing over $\$ 1$ bln and recently reached historical maximums both in numbers and in cost of mergers [20]. The increase in pharmaceutical mergers and acquisitions activity demonstrates, that the yearly number of such agreements permanently rises (from about 100 at the end of 1980s till almost 800 in 2015) [6].

To compensate the price of the drugs, the companies invest the spent costs into marketing and distribution. When the drug loses the patent protection, the company switches its focus to the research of new drugs with the potentially high sales volume and margin to support its marketing mechanisms. If the company does not have the mentioned researches, it purchases another pharmaceutical company, which has it and thus can use its marketing possibilities. This is one of the explanations of the need of mergers: big pharmaceutical companies cannot fill their marketing channels and they acquire other companies to sustain stable deliveries.

Such interpretation provides the possibility to suspect, that the merger can be an attempt to compensate the lack of new innovative products within the portfolio of big pharmaceutical companies. To encash the investments into marketing and distribution, such pharmaceutical giants should acquire companies with new products, which give sustainable profits and are interesting for the consumer [9].

Thus, the pharmaceutical companies make mergers and acquisition agreements, as they are not developing any new products, and they merge to hide their blemishes.

It means, that we can talk about current mergers as a sign of industry volatility. Low profits and lack of innovation are the reasons for the merger for the initiating companies. Furthermore, in future such mergers need a lot of funds for the integration. Taking this into account, the state, constantly monitoring the mergers, has to interfere to prevent mergers of big pharmaceutical companies. In case, if the total price of the company after the merger becomes lower, such merger should be banned regardless of its effectiveness, which excuses the additional market concentration.

The prices of pharmaceutical products in USA and worldwide have increased dramatically during last 2-5 years [10]. However, it is an ambiguous question whether the increase of mergers and acquisitions has anything to do with this fact. There is no doubt, that pharmaceutical products prices increase creates fiscal dangers for both private and state budgets [5]. However, there is no fixed dependency between mergers and acquisitions and the increase of concentration in pharmaceutical industry [17]

Furthermore, the drugs prices increase can be a bit deceptive as it shows the actual market prices. Insurance companies, healthcare facilities, pharmaceutical companies' managers and other subjects of market power, are negotiating huge discounts. The high level of the consolidation of suppliers and payers was observed during recent two decades because of the incorrect usage of antimonopoly legislation. This consolidation lead to 
prices increase for consumers in the healthcare system, increasing the market power of suppliers and demanding discounts from the pharmaceutical producers [12].

It seems, that the individual price increase is the result of activity of certain market structures. Some examples of prices increase show, that the companies use the possibility to increase prices on generic drugs. It means, that a lot of newly created pharmaceutical companies pay more attention to specialized drugs and drugs produced with innovative methods. In its turn, it can lead to changes companies market segmentation strategy for those of them, which work on in competitive markets.

Such behavior of pharmaceutical companies allows to make conclusions on the market power evaluation priority on the level of functional equivalents and not on the worldwide indexes, i.e. the way the antimonopoly regulators see the suggested mergers.

Companies' pricing strategy is also important. It should correlate with the companies' segmentation strategy and the market niche the company would like to occupy within which the competitors would be releasing new products with delays.

Such delays are sensitive towards the existing legislation, as it facilitates or hurdles the entrance to the market. The "delay" means, that regardless of the competition in generic drugs production and the prices increase, the company will still be influential on the market, until another company releases the drug-competitor. It should be also considered that sometimes it takes years to release a new product. It means the first company has time to have super-profit via controlling the prices [4, p.75].

Taking into account the pharmaceutical market work peculiarities, its segmentation specificity and pricing, the antimonopoly authorities should be monitoring such markets and evaluating the merger to prevent the pharmaceutical competitors to enter the market or to have a new pricing power in the scope of a certain pharmaceutical space.

Some scholars assume, that the potential mergers prices influence can decrease the innovative activity in the industry. It is important to understand, that the industry consolidation leads to increase in price, but decreases the motivation to innovate. Also, the mentioned processes lead to decreased productivity in research and development in big pharmaceutical companies: less innovative decisions are taken, less valuable discoveries are done and the drugs, duplicating those already existing on the market are produced [19, p. 156].

Nevertheless, on our opinion, there is another pharmaceutical market trend observed. The innovation location is changed from big companies to small startups and firms, which work from non-traditional geographical markets. It leads to structural transformation of pharmaceutical industry and merger number rise reflects this trend. Traditional big pharmaceutical companies do not have enough experience in this scientific area, which allows smaller companies to enter the market. The scientific biological research is not developed enough yet and since the capital assets are not sufficient, the strategic mergers and acquisitions are done for the sake of enlarging marketing and distribution possibilities of both enterprises.

Another crucial change on the market is the decrease of spending and resources needed to implement important innovations. Today the role of information technologies (IT) in research is vital. IT makes it much easier to transfer and receive the information for 
fundamental research. It leads to the possibility for small enterprises to implement important innovations while staying small. The new pharmaceutical treatment methods discovery competition is constant and the consolidation of big pharmaceutical companies does not pose any danger for the competitiveness of the innovations market.

Though big pharmaceutical companies do not have the dominating influence on the innovative discoveries, they still have the comparative advantage before the small companies in terms of the distribution marketing networks in many countries. Small drugs developing companies usually do not have enough marketing power to deliver their product to the global markets on the own.

This is the reason why many small companies conducting important innovative research tend to sell their innovative products or even the whole company [15]. Such agreements ensure the effective way to use the existing investment into the big company marketing system and it explains an increase of number of mergers and acquisitions during past two decades.

Another comparative advantage the big companies possess is the access to sufficient funds to receive all the necessary approval documents for the new product development. It is vitally important during the early stage of research to fund the testing. It becomes a reason for many startups to sell their discoveries to big pharmaceutical companies before the approval process started or before commercialization .

Big pharmaceutical companies play another role in drugs production accordingly. Instead of being innovations creators investing to R\&D and lead the discoveries process, such enterprises are functioning more and more as innovations acquirers and provide added value to regulatory and commercialization processes.

Merging two research departments into one allows to cut the expenses for research and fuel the new discoveries competition. Even if the internal research productivity of big pharmaceutical companies has decreased, such companies became innovations purchasers. Same applies also in case, if the companies continue to create innovations and their supply feeds the development process and allow to commercialize many new products.

Merger and acquisition processes also cause changes in the management systems of the enterprises. Mergers often cause the resignation of the management. A lot of them create their own companies later and help to finish the research already started on their previous place of work and commercialize the product. "Virtual companies", which do not conduct any research or clinical trials, can also be created. Such companies are managing the development up to commercialization via contract agents. Appearance of such enterprises shows that the pharmaceutical industry is going through structural changes, which facilitate the solution of many problems of concentration in the industry.

In current conditions of the budget cuts and harsh epidemiological challenges the question arises, whether small R\&D companies (any startups), virtual companies, using contractors services, will be able to find funding for serious clinical trials or whether such structural changes can hurdle the competition. Venture capital, which is appearing in the healthcare sector, can mitigate any monopsony of the big pharmaceutical companies in terms of new innovative products development. Healthcare industry venture financing has 
increased dramatically during few recent years even though big pharmaceutical companies are increasingly relying on innovation purchasing (it is very possible, that more, than $25 \%$ of the general sales volume of the twenty biggest pharmaceutical companies is coming from a licensed products).

Even though the number of venture capital investors has decreased during the last cutback of economic activity, such kind of funding will remain an important part of healthcare industry innovation in years to come.

However, venture capital is still quite a risky investment. Venture capital markets are not able to adequately fund the innovation process. This is the reason why big pharmaceutical companies with a lot of funds and sustainable current drugs sales profits sources will have an advantage on the medical innovations market.

Though the venture funding and third-parties funding has slowed down during recession, the companies of all sizes are still able to raise funds to promote the developments and the market must stay real for its subjects. It does not concern big pharmaceutical companies as recently the megamergers do not have enough development market concentration to damage the innovations.

Thus, only the sufficient number of companies, which are able to develop discoveries up to its commercialization are still on the market.

The increase of the number of virtual companies, which are conducting testing during the implementation stage and other big companies (some employees of which were dismissed after the merger happened) have created an active and competitive market for discoveries development and commercialization. And even if the boom of the activity in merger and acquisition sometimes delays the innovative production, the acquisitions seem to be an integral part of the product development and future long-tern innovative activity foundations creation. These actions have reduced the uncertainty regarding the decrease of discoveries competitiveness as a result of companies' mergers.

Thus, we experience important structural changes in medical research. Innovations are being created in startups more and more often and big pharmaceutical companies are relying more and more on licensed products. Furthermore, the megamergers are potentially concentrating the market for the purchasers of innovations and it leads to serious changes in the drugs discovery.

Conclusions. Pharmaceutical industry demonstrates big structural changes, which signifies the significant increase in number of the merger and acquisition agreements common for industry. We have demonstrated the proof that the prevailing pharmaceutical companies' mergers can have different consequences. The possibility to create the competitive innovations forms the powerful market for new pharmaceutical products development, where the megamergers can be not only the threat, but can also serve to activate the market. The active venture capital and biotechnological financing market together with research organizations and virtual companies can create the competitive environment on the biotech market, though the megamergers, having a certain market power, can be setting it back.

Perspective of future development. Considering the peculiarities of the pharmaceutical market development and mergers and acquisitions agreements specificity, 
it should be additionally studied, whether the megamergers are able to oppress innovations in scopes of this new industry paradigm and whether such mergers pose threat for the industry development.

\section{References}

1. Biggest Mergers and Acquisitions of 2015 [Electronic resource]. - Access: http://investorplace.com/2015/12/2015-mergersandacquisitions. - Last access: 12.02.2017. - Title from the screen.

2. Bloomberg-Global-MA-Financial-Rankings-1st-3Q2016_NEW [Electronic resource]. - Mode of access: https://data.bloomberglp.com/Bloomberg-Global-MA-Financial-Rankings1st3Q2016_NEW1.pdf. - Last access: 5.10.2019. - Title from the screen.

3. Bloomberg-Global-MA-Legal-Rankings-1st-3Q2016 [Electronic resource]. - Mode of access: https://data.bloomberglp.com/professiBloomberg-Global-MA-Legal-Rankings-1st-3Q2016.pdf. - Last access: 5.10.2019. - Title from the screen.

4. Bruno Cassiman \& Massimo G. Colombo, (2006). Mergers and Acquisitions: the Innovation Impact . Edward Elgar Pub. - 200 p.

5. David Blumenthal \& David Squires, (2016). Drug Price Control: How Some Government Programs Do It, Common Wealth Fund, [Electronic resource]. - Access: http://www.commonwealthfund.org/publications/blog/2016/may/drug-price-control-how-somegovernment-programs-do-it.

6. Eurostat.-[Elektronnyi resurs].-Rezhym dostupu: https://ec.europa.eu/eurostat]

7. EY-global-ipo-trends-2018q3 [[Electronic resource]. - Access: http://www.ey.com/Publication/ EY-global-ipo-trends-2018q3/\$FILE/EY-global-ipo-trends-20186q3.pdf. - Last access: 18.02.2019. Title from the screen

8. James Fontanella-Khan, (2016). Pharma M\&A for 2016 Continues to Surge, FIN. TIMES, [Electronic resource]. - Access: https://www.ft.com/content/9adbce94-c902-11e5-be0b-b7ece4e953a0.

9. Kearney A.T., (2010). Mergers and Acquisitions in the Healthcare Industry, [Electronic resource]. - Access:

https://www.atkearney.com/documents/10192/256759/MA_in_Healthcare.pdf/6f7857c3-80d5-4020$89 f c-8 e f 86 a b b 94 b c$.

10. Kravchenko T.V., Nosenko V.V. (2018). Efektyvnist M\&A uhod ta yikh vplyv na konkurentospromozhnist Ukrainy . Teoretychni ta prykladni pytannia ekonomiky [Theoretical and Applied Economic Issues], no. 2, pp. 135-143

11. Levkivskyi, V. M. (2016). Zlyttia ta pohlynannia v stratehii zarubizhnoi ekspansii TNK. Naukovyi visnyk Polissia. [Scientific Bulletin of Polissya], no. 2, pp. 9-15

12. Linda A. Johnson \& Tom Murphy, Drugmaker Mylan, (2016). Launching Cheaper EpiPen Following Price-Hike Backlash, TORONTO STAR (Aug. 29, ), [Electronic resource]. Access: https://www.thestar.com/business/2016/08/29/drugmaker-mylan-launching-cheaper-epipenfollowing-price-hike-backlash.html.

13. Peter Young, ( 2016). Biotech Financial and M\&A Trends-Two Steps Forward, One Step Back, [Electronic resource]. - Access: http://www.pharmexec.com/biotech-financial-and-ma-trends-two-stepsforward-one-step-back.

14. Pobochenko, L.M. (2018) Suchasni tendentsii rozvytku protsesiv zlyttia ta pohlynannia $v$ hlobalnomu biznes-seredovyshchi. Mizhnarodni vidnosyny: teoretyko-praktychni aspekty, [International Relations: theoretical and practical aspects], no. May.- DOI: 10.31866/2616-745x.1.2018.133425

15. Press Release, Fed. Trade Comm'n, FTC Requires Teva to Divest Over 75 Generic Drugs to Settle Competition Concerns Related to its Acquisition of Allergan's Generic Business (July 27, 2016), [Electronic resource]. - Access: https://www.ftc.gov/news-events/press-releases/2016/07/ftc-requiresteva-divest-over-75-generic- drugs-rival-firms-settle. 
16. Quintilesims, Top Line Market Data: Top 20 Global Products 2015, 1, [Electronic resource]. Access:

https:/www.imshealth.com/files/web/Corporate/News/TopLine\%20Market\%20Data/Top_20_Global_Pro ducts_2015.pdf

17. Strapchuk, S.I. (2017). Strategy of merger and acquisition as the alternative of pharmaceutical companies' growth in a short-term perspective. Economika i suspilstvo [Economy and society], no. 9,pp. 673-677

18. Sabadash, V.V. (2015). Mergers and acquisitions markets: state, functioning problems, and development trends. Mekhanizm rehuliuvannia ekonomiky [Mechanism of Economic Regulation], no. 4, pp. 127-138.

19. Swen Hoelder et al., (2012). Discovery of Small Molecule Cancer Drugs: Successes, Challenges and Opportunities. MOLECULAR ONCOLOGY, pp. 155- 169.

20. Thomson Reuters' Investment Banking Deal Activity. SDC Platinum Database, THOMSON REUTERS, [Electronic resource]. - Access: http://financial.thomsonreuters.com/en/products/dataanalytics/market-data/sdc-platinum-financial-securities.html

Двуліт 3.П., д.е.Н., профресор

Національний університет «Львівська політехніка»

Миккитюк О.П., к.е.Н., доцент

КНУ імені Тараса Шевченка

Онисенко Т.С., к.е.н.

КНУ імені Тараса Шевченка

\section{Особливості процесів злиття та поглинання у фармацевтичній промисловості}

Підвищення обсягів злиттів та поглинань в фармацевтичній галузі викликало побоювання, що безпрецедентна концентрація ринку послабить конкуренцію. Дві з найбільш важливих проблем, що стосуються фрармацевтичної промисловості: стурбованість тим, що ці злиття приведуть ринок до зменшення нових розробок, та занепокоєння, що об'єднання великих маркетингових зусиль і продажів посилить вплив окремих виробників фрармацевтичних препаратів і послабить конкуренцію у галузі.

у даній статті стверджується, що жодна з зазначених вище небезпек не є систематично виправданою. Втім, існує потенційна небезпека концентрації ринку на етаni регуляторного схвалення злиттів і поглинань.

У статті визначається, як ці структурні зміни сприяють поточній хвилі злиттів серед активних учасників фармацевтичного ринку яким чином можна зменшити потенційну шкоду конкуренції .

Ключові слова: злиття, поглинання, угоди об'єднання, фармацевтика, поєднання інтересів, підприємство 
Двулит 3.П., Д.э.Н., професссор

Национальный университет «Львовская политехника»

Микитюк О.П., к.э.Н., доцент

КНУ имени Тараса Шевченка

Онисенко Т.С., к.э.н.

КНУ имени Тараса Шевченка

\section{Особенности процессов слияния и поглощения в фармацевтической промышленности}

Повышение объемов слияний и поглощений в фармацевтической отрасли вызвало опасения, что беспрецедентная концентрация рынка ослабит конкуренцию. Две из наиболее важных проблем, касающихся фрармацевтической промьшленности: обеспокоенность тем, что эти слияния приведут рынок к уменьшению новых разработок, и беспокойство, что объединение крупных маркетинговых усилий и продаж усилит влияние отдельных производителей фрармацевтических препаратов ослабит конкуренцию в отрасли.

В данной статье утверждается, что ни одна из указанных выше опасностей не является систематически оправданной. Впрочем, существует потенциальная опасность концентрации рынка на этапе регуляторного одобрения слияний и поглощений.

В статье определяется, как эти структурные изменения способствуют текущей волны слияний среди активных участников фрармацевтического рынка каким образом, можно уменьшить потенциальный вред конкуренции.

Ключевые слова: слияние, поглощение, соглашения объединения, фрармацевтика, сочетание интересов, предприятие 